\title{
Found Footage Filmmaking and Popular Memory
}

\author{
By Desmond Bell
}

Spring 2004 Issue of KINEMA

SHOOTING THE PAST? FOUND FOOTAGE FILMMAKING AND POPULAR MEMORY

\section{Introduction}

How should we as documentary filmmakers picture the past? How should we conduct the struggle for memory? Clearly a major resource for the representation of history and the celebration of popular memory is the treasure trove of archival images, both still and moving, that are now available to us in the photographic and film archives. But how should we deal with this stockpile of images - as primary evidence and mute testimony to a unattainable past or as narrative resource capable of releasing the submerged voices of history and of attending to their story?

Over the last number of years in collaboration with my editor Roger Buck at Napier University, I have developed an archivally based, creative film practice which explores aspects of Ireland's post- Famine past and the Irish diaspora in America. The Hard Road To Klondike (Bell: 1999) drew on a rich reservoir of early film material both actuality and fictional in order to retell the classic Irish emigrant story of Micí MacGiobhan's tramp through frontier America to the Yukon. The Last Storyteller? (Bell: 2002) concerned itself with the work of the Irish Folk Lore Commission and its veteran collector Seán Ó hEochaidh and mused on the eclipse of traditional storytelling. It used similar archival strategies to those employed in Klondike to retell some of the uncanny and provoking fairy and folk tales collected by Seán in Donegal from the 1930s to the 1950s. ${ }^{(1)}$ My latest film, Rebel Frontier (Bell: 2004) again uses archival material and in this case a fictionalised narration based on actual historical sources in order to tell the story of the Irish and Finnish miners of Butte Montana and their struggle against US involvement in the First World War.

In this paper I seek to make sense of my own creative documentary work and its use of archive material as both historical trace and as narrative resource. Let me list the issues which I wish to explore here: the evidential status of photographic archive within the contemporary documentary film; the use of voiceover and related issues of subjectivity; the role of fictive tropes and strategies within factual filmmaking. How should we as filmmakers and indeed as historians operating in and through documentary film practice evaluate the evidential and expressive status of the still and moving archival image? What, in other words, are the ethical, epistemological and creative issues involved in handling the shifting boundary of fact and fiction in the creative documentary?

Needless to say my approach is that of a practitioner concerned with illuminating the creative and critical auspices of my own work rather than that of a film theorist per se. Filmmaking is always an exploration and testing of ideas about the medium, its creative capacities and its mode of public address. Film Studies has become over abstract as a discipline and as it has become more institutionalised within the academy a wedge has been driven between theoretical work and a living film culture. On the other hand, avant-garde film practice within which critical theory and creative practice were often in a productive alignment has become increasingly marginalised within the film and television industry. Perhaps we need to acknowledge the potential contribution that practice-based forms of analysis might make to addressing these material problems within film culture. One of the challenges of practice-based research is to encourage artists to engage in auto-critique. Can the filmmaker/ researcher render explicit the form of tacit knowledge arrived at in and through their practice by engaging in a process of reflective appropriation?

\section{The Mummification of History}

Theorist Joachim Paech (1989: 59) reminds us of the preservative power of the archival image, "The ephemeral historical moment becomes a permanent presence in the moving image in these archives of history". The photographic image, still or moving, as Bazin observed (1981), embalms or mummifies history providing in its visual trace a "second degree original". Within the traditional television documentary with its journalistic auspices photographic sources are treated as transparent to the historical reality they purport to depict and accordingly as primary evidence. But these evidential claims rest on a particular understanding 
of the photographic image. In Paech's words, "The signifying material has to become invisible in favour of the intensified visibility of the signified" (58).

The indexical character of the photographic image is seen to underwrite the documentary's claim to facticity. The photographic image signals the presence of the camera on the scene at the historical moment of image capture. Pioneer film theorists like Bazin and Kracauer (1960) drew a strong association between the indexical character of the photographic image and the primacy of realism as a code within cinema. Both this understanding of photography and the privileging of realism ${ }^{(2)}$ have shaped the conventional notion that documentary film is primarily an instrument of unproblematic observation and record capable of being pressed into didactic service.

However in a digital age we have all become more sceptical about the indexical claims of photography and more aware that the use of archive by documentary filmmakers is influenced by other considerations other than the purely evidential - after all we are storytellers first and foremost.

Across a range of disciplines, social anthropology, historiography, geography, cultural studies, there has been a recognition of the transformative powers of narration with regards to the assemblage of empirical fact and its communication to an audience via a mass medium. Indeed is strange that narratological concerns have up to now played such a limited role in the discussion of documentary film. This is largely to be explained by the assumed primacy of photographic practice within this filmic form and by the claims to verisimilitude thought to reside in magical powers of "the pencil of nature". In addition, as Bill Nichols (1991) points out, a "discourse of sobriety" shrouds documentary film closely related to its didactic public educational role. This serves to insulate the documentary from the fictive and commercial contaminations of Hollywood but it also obscures the role of figuration and narration with the creative strategies employed by non-fiction filmmakers.

The departure point for the new documentary criticism (Nicholls 1991, 1994, 2001, Bruzzi 2000) has been an engagement with the realist claims traditionally made for the documentary film and a recognition that contemporary creative documentary practice has begun to problematise the boundary between the factual and the fictive.

\section{The Films}

The projects I wish to discuss were largely based on autobiographical sources and on a creative appropriation of a wide range of archive material. Klondike was adapted from Micí Mac Gabhann's account of his upbringing in Donegal on the north western seaboard of Ireland and his subsequent travels as a migrant labourer in Scotland and the US. His story was transcribed by folk lore collector Seán Ó hEochaidh and subsequently published in book form, first in Irish and subsequently in an English translation. In turn, Storyteller draws on the field diaries Ó hEochaidh's kept as collector for the Irish Folk Lore Commission. These give an account of his life as a collector in Donegal from the mid 1930s to the 1970s. Both films involved extensive historical research on the lives of Irish migrant workers and on folk belief and social practice in the western sea board. Both draw on a rich reservoir of archival images, still and moving, portraying rural life in the west of Ireland from the 1930s to the 1950s and in the case of Klondike on early US silent cinema. Both films are narrated by Irish actor Stephen Rea. Rebel Frontier employs a fictive autobiographical voice (narrated by Martin Sheen), ostensibly that of a young Pinkerton agent, to provide witness to the dramatic events unfolding in Butte in 1917 as the town's miners find themselves locked in a titanic struggle with both the Anaconda Mining Company and the US state.

The archival collages, which are a feature of all three films, use both actuality material, both professionally shot and of home movie origin. They also use material from fiction films. No attempt is made to distinguish between these sources in their assembly and in my films. Archival sequences are removed from their original narrative context whether these be fictional or documentary films and employed as a narrative resource within new story structures. In other words, the archive material is not used as it is in many television documentaries to illustrate a didactic argument primarily established via an authoritative voice-over. Nor is it used as presented evidence of a now gone way of life. The relationship between the voice-over and the found footage in these films is not of a "point and see" character. Word and image lack an ordered referentiality. In both films images are often assembled with a view to achieving expressive force or to probe the veracity of accounts rather than as evidential proof. 
Take, for example, the sequence in Klondike which portrays the arrival of Micí Mac Gabhann in New York in the 1890s on board an emigrant ship. Stephen Rea voices Mac Gabhann's commentary,

On the eleventh day it was announced we were coming near New York. I gathered myself and tried to move around a bit

New York was like a dream. I gazed wide-eyed at Manhattan and wandered through its streets in a daze

This scene is "covered" visually with a montage made up of the following elements:

- Sequence from the Kalem 1910 fiction feature The Lad From Old Ireland showing emigrants on the deck of passenger boat

- Live action photography scenes of Liberty Island and lower Manhattan and of tenements and homeless people on the streets of the lower east side

- Sequence from Edison's New York paper collection, circa 1903, showing a cop moving on a street trader, a scene clearly posed for the camera.

- Sequence from The Lad From Old Ireland showing the hero (played by Kalem director Sydney Olcott) on the New York quayside caught up in the bustle of the port.

- Trick film sequence (speeded up time lapse) of the erection of the Star cinema from the Edison New York Paper Collection, 1902.

- Sequence from the 1901 Edison variety What Happened on 23rd Street portraying an iconic moment in which a girl's dress is lifted by rush of hot air from a sidewalk vent.

This montage involves then fictional elements, period actualities of New York, short varieties of staged incidents and live action footage seeking to capture the historical resonances in the contemporary city. As in other found footage films, no attempt is made to discriminate between these different sort of footage by the use of any framing or titling device (although at one point the sound track with its dubbed sound of a cine projector at work does explicitly invite the audience to peep into a cinema of attractions).

I guess when we were assembling this sequence we had in mind the historical reality that for many of the newly arrived emigrants their first port of call in the city may well have been the nickelodeons of Broadway to view salacious Edison varieties like What Happened on 23 $3^{\text {rd }}$ Street. With this introduction to cinema came also a new way of narrating and remembering. Cinema became both a conduit delivering "the shock of modernity" but also as it developed its power of storytelling (Gunning 1994) a reservoir of memory. Its fairly clear for instance that Mac Gabhann's epic is indebted in its narrative drive and descriptive economy to post-Griffith popular cinema.

The key feature of these films is, I would argue, their handling of visual archive, both still and moving, in conjunction and counterpoint with a particular sort of voice-over. In marked contrast to the authoritative and disembodied voice of the expository documentary, Klondike employs what I call a vernacular voice (that is a voice-over that in its commitment to storytelling reveals its own partiality). At the beginning of the movie, Rea, sleepily intones over archival images of the Aran islands in the 1930s (Mac Gabhan was born in 1865 and in north west Donegal, two hundred miles north of Connemara),

It's not easy for this generation to understand life as it was when I was young. Often now as I think back I feel as if I dreaming.......

Neither books nor papers were available to my people. Hardly more than two families in the whole parish had a clock - we relied only on the sun or moon...

It was little we had to do with the outside world except for the news a travelling man would bring from time to time

The voice-over has acquired a terrible reputation as a documentary device within "smart" film circles. This is to no small degree due to its insensitive use within television documentaries and factual programming where its tone is often didactic. The "voice of God" narration can easily overwhelm the visual aspect of the film reducing the complexities of the image to a tautological confirmation of what we are being told. However things do not have to be like this. In the history of documentary film, in the work of directors 
like Buñuel, Franju, Ford and Marker for instance, we find different varieties of voice-over - narrations that are ironic and detached, poetic and partial, vernacular and engaged. The use of such a voice can have a profound impact on the "reality effect" of the documentary film. A certain orthodoxy has grown up within film criticism about the contaminatory effect of the voice-over within documentary film. This has been blind to the creative and critical potential of what we might call the embodied voice-over (as distinct from the "voice of God" narration).

The greatest champions of this orthodoxy have been the proponents of "direct" or observational cinema with their dogmatic argument that only documentaries structured without resort to voice-over can attain cinematic form. As a filmmaker I found myself initially attracted to this radical orthodoxy which incidently also has its adherents among television commissioning editors. Direct cinema's refusal to fall back on voiceover to solve problems of structure, continuity and intelligibility seemed like a bold step which set other filmmakers a creative challenge. Actually it was only after attending more closely to the use of narration in fiction film - namely those of the Nouvelle Vague and in America of Terence Malick - that I as a practitioner began to re-evaluate this orthodoxy. Exposure to the films of Chris Marker with their ironic, probing and highly individual voice completed my conversion to a "revisionist" position on the voice-over. Interestingly Stephen Rea was to tackle a vernacular voice-over in his work on Neil Jordan's The Butcher Boy (1997) several years before he performed the narration for Klondike and of course Martin Sheen has given us an exemplary performance to accompany Sissy Spacek's haunting voice-over in Malick's Badlands (1973) and delivered a memorable voice-over himself for Francis Ford Coppola's Apocalypse Now (1979).

Clearly the use of the vernacular voice within documentary film raises particular issues. Among these is that of point of view and of the truth status of the enunciated. It has long been taken for granted that the question of point of view is a key one within fiction but strangely this issue is often buried in discussion of documentary film. Within the fiction film the establishment of a film's point of view is usually signalled by camera perspective (indeed that is one of the original and restrictive meanings of the term). Within the documentary the qualities of voice-over - its timbre, cadence, resonance and acuity - are often more important. Certainly for me the choice of Stephen Rea as the narrator of both Klondike and Storyteller, and of Martin Sheen for Rebel Frontier was critical as their skill as actors was crucial in establishing both the tone and point of view of these films. In both films while interview testimony is included to provide additional sources and perspectives, the films achieve their narratological unity in the performances of Rea and Sheen respectively.

But what of the choice of archival images in these films? As we have seen both use clips from both actualities and fictions combined apparently willy nilly. The use of the factual archive is on occasions not strictly bound by concerns with historical and geographical accuracy. Are these films documentaries? Is the filmmaker guilty of playing free and easy with documentary sources? Is he involved in some sleight of hand in this blurring of the boundaries between fact and fiction?

\section{Fact and Fiction}

Nichols (2001) has offered us a distinctive typology of documentary film within which he traces the evolution of the genre ${ }^{(3)}$ from an early expository mode still favoured by television and characterised by its didactic form and use of an obtrusive and omniscient voice-over, through the observational and interventionist modes associated with the mobile camera and fly on the wall techniques of cinema vérité, to what he calls "performative documentary". Most filmmakers working for television have experience of employing both the expository and observational modes and today these are often combined in films which frame observational sequences within structures of exposition utilising voice-over. Television executives still believe that such explanatory voice-overs are necessary in order to contextualise vérité material for a popular audience. I myself have made two such films for the UK's Channel Four Television on the subject of Ulster Loyalism, Redeeming History (Bell: 1991) and Out of Loyal Ulster (Bell: 1994) where the imperative to explicate and explain Irish affairs to an English audience envisaged as being unlikely to be able to comprehend the complexities of Irish history, was an implicit clause in the commissioning contract.

Performative documentary, on the other hand, offers its viewer neither the objective summation of events promised by the expository mode nor the lived immediacy and voyeuristic thrills of the observational form. Instead the filmmaker draws on a disparate set of resources - found footage, re-enactment, personal sources 
and sentiments - and employs a range of creative strategies - experimental collage, use of vernacular voices, visual forms of telling - in order to communicate a much more partial, often emotionally charged and questioning account of an issue or event.

The performative mode is characterised by both formal innovation (experiments in using and reframing found footage, the inclusion of the filmmakers' presence and performance within the film, recourse to fictional strategies, the development of visually led form of telling) and by a certain scepticism with regards the truth claims of filmmakers, their interviewees and indeed the entire cinematographic apparatus. Within this approach questions of authority (who knows and who gets to speak) and of evidence (the verisimilitude of presented observation and testimony) are problematized and a much greater emphasis is placed on the subjectivity of the filmmakers than on the objectivity of the photographic medium. Filmmakers adopt disparate aesthetic strategies to communicate with audiences across a range of expressive as well as cognitive registers. Reality is longer captured unproblematically via the camera lens but patterned via the filmmakers' aesthetic constructions.

Radically different strategies for using archival sources have emerged within the performative mode of documentary to those found in expository and observational documentary.

\section{Found Footage Filmmaking}

Nichols (2001: 137) draws our attention to the work of the Hungarian filmmaker Peter Forgács as exemplified in his 1996 film Free Fall. This film relies entirely on found footage to evoke a sense of wartime Hungary and of impending disaster about to befall the Jewish community. It reworks this found footage, slowing down sequences, cropping images or blowing them up, establish cutting rhythms against music and elaborating abstract visual forms. In other words Forgács employs a series of digital post-production strategies to both draw in the spectator emotionally into the unfolding story but also to force them to question the status of the images they are seeing as documents and of the voices they are hearing as narrators. Forgács earlier work Wittgenstein (1994) had a profound impact on me when I first saw it in Budapest in the offices of Magyar Television. In this series of short film episodes produced for Hungarian state television, Forgács first drew upon a corpus of home movie footage found in a Budapest attic and which he has used in a number of his later found footage projects including Free Fall.

The director discovered this home movie hoard in the early 1990s. It belonged to one Hungarian middle class family and covers the period from the 1930s through to the 1950s. In Wittgenstein Forgács reworks this material slowing sequences down, reframing shots, using digital wipes in order to evoke the Austrian philosopher's reflections on language, vision, suffering and death as contained in his magnus opus the Tractatus (1981). There is absolutely no referential relationship between the written words of Wittgenstein we hear intoned by an actor in the voice-over and the archival images we see of a bourgeois family at play often in a rural setting. Yet word and image resonate in a manner that profoundly illuminates our understanding of each. Is Wittgenstein a documentary, performative or otherwise? It surveys no original documents associated with the philosopher and seeks no opinions from witnesses about his life and work. Nor is it the story of the writing of his book, still less of his life and times. In truth it is a meditation on aspects of Wittgenstein's metaphysics, particularly his theory of meaning, a meditation performed in and through attention to the filmic medium and its signs.

Joachim Paech (1989) draws our attention to Edgardo Cozarinsky's extraordinary film One Man's War (1982). This draws upon factual film footage of Paris under the Nazi occupation as captured in Vichy-Newsreels. The facticity of this photographic record is thrown into some disarray by the cutting of these images against a voice-over based on the obliquely observed diary entries of Ernst Jünger, a Wehrmacht officer stationed in Paris. Each source provides a different view of the occupation with the prosaic and coolly distant narration of Junger simultaneously undermining both the photographic verisimilitude and the ideological claims of the Vichy newsreel and producing what Paech has called, "a de-realization of the code of the real". Like Forgács, Cozarinsky both celebrates the indexical power of the archival image and its capacity to salvage a sense of the past, while systematically undermining the truth claims of the photographic sources. He does so by placing them in counterpoint with a form of narration which questions rather than confirms the meaning of what we are seeing.

More recently Bill Morrison in his pieces Film of Her (1996) and Decasia (2002) has drawn on the Library of 
Congress early paper collection to explore the historical materiality of moving image archive. Working with severely degraded footage that bubbles and explodes in front of our eyes he directs our attention away from the objective referent of these images and towards the historical life of the film material itself. These highly expressive found footage works seem to pose a series of questions about the status of the archival image and more generally about the truth practices of documentary film.

For Catherine Russell (1999: 240) found footage filmmaking approaches the archival in a distinctive manner,

In the process of being appropriated, the original image

gives over its meaning to the new text and is manipulated

by the new film maker on the level of the signifier.

Within the found footage film the meaning of the archival elements employed by the filmmaker is transformed as these images are compiled together in a new text. The original material is used in ways that pose serious questions for both documentary theory and practice.

In developing her analysis of found footage filmmaking, Russell draws upon Walter Benjamin's theorization of memory as an aesthetic of ruins and traces. The ruin for Benjamin is both the most material and most symbolically powerful form of the allegorization of history. Its fragments are testimony to what has gone before but are also indicative of a loss that can never be repaired. The photograph is like a ruin, in that it is always an incomplete indexical record of what it purports to represent. The record has to be read and this requires a critical engagement at the level of representation. Benjamin, Russell believes, offers a critical solution to one of the recurrent problems faced by post-structuralist thought, "how to theorize cultural memory without mystifying it as an original site" (Russell 1999: 8). The found footage film does not seek to offer the immediate, indexical access to the past promised by the original photographic sources from which it is assembled. For in the found footage film the images are all mixed up. Combined together under a montage principle, they establish a different sort of relationship with the past to the denotational claims made for the individual photographic image. The relationship of archival element to historical event becomes a figurative rather than referential one. For Russell (1999:238)

Its intertextuality is always also an allegory of history, a montage of memory trace which the film maker engages with the past through recall, retrieval, and recycling.

Accordingly,

The complex relation to the real that unfolds in found - footage film making lies somewhere between documentary and fictional modes of representation opening up a very different means of representing culture.

The found footage film like the performative documentary more generally, plots a space between fact and fable. This could be said of most storytelling.

\section{Documentary as a Radical Form of Memory}

My own films explore a range of found footage and voice-over strategies. They do so with a much stronger narrative steer than the other artists I discuss above. My approach seeks to be responsive to the original folk lore material I have drawn upon which in turn is rooted in a Gaelic oral tradition of storytelling. Indeed, what distinguishes the Klondike, Storyteller and Rebel Frontier voice-overs from the ironic postmodern voice employed in the Cozarinsky and Forgács films is this rootedness in a storytelling tradition and attention to the role of narrative in relaying popular memory. As cinema activist Teshome Gabriel argues (1986:53),

Memory does something else beside telling us how we got here from there: it reminds us of the causes of difference between popular memory and official versions of history.

Thus The Hard Road To Klondike seeks to remain faithful to a traditional practice of storytelling while drawing on the figurative powers of the photographic image. Stephen Rea narrates the film from a script which is fairly faithfully based on Mac Gabhann's transcribed and published account of his travels Rotha Mór an tSaoil (1959). The film recasts the autobiographical recollections of one particular migrant worker and his passage to the new world. Micí Mac Gabhann's story is a thoroughly modernist one speaking as it does 
to a wider experience of colonised peoples and of diaspora. Gabriel has coined the term "hetero-biography" to identify a modality of autobiographical narrative found in third cinema (1986: 58),

I do not mean autobiography in its usual Western sense of a narrative by and about a single subject. Rather I am speaking of a multi-generational and trans-individual autobiography, ie a symbolic autobiography where the collective subject is the focus.

A critical scrutiny of this extended sense of autobiography...

Is more than an expression of shared experience; it is a mark of solidarity with people's lives and struggles.

Mac Gabhann's distinctive story speaks then to a wider experience of colonised peoples not only via his account of his passage to the new world but in his relationship to the native American peoples he encounters in Montana and later in the Yukon. And indeed it is Mac Gabhann's capacity as a storyteller to lift his narrative out of the sentimental reminiscence of the emigrant and to address issues of solidarity and difference between his historical experience as a Gael and that of the Indians marginalised by miner-settlers like himself, which shaped our reading of his text.

In the section of the film where this theme is most fully explored I assemble a number of documentary elements. Stephen Rea voices Micí Mac Gabhann's account of his dealings with the native Americans,

Narrator

The valley below us was inhabited by Red Indians and strange rugged featured men they were who gave their name to the river below us the Great Blackfoot.

The Indians that were left here were in a bad way and we had a great deal of pity for them. We knew their plight well trying to hold onto the lands of their ancestors with greedy white men trying to get their hands on it

This narration is dubbed over shots from the Ford Collection of Blackfeet Indians circa 1922, combined with stills from the 1870s portraying US troops and native Americans during the Indian Wars in Montana. The film then cuts to contemporary native American artist and historian Gary White Deer speaking to the camera on the subject of the historical decline of Blackfeet culture which he traces to the assault of miners and settlers like Mac Gabhann. We then see the early Edison actuality Indians Receiving Rations (1897) one of the most remarkable documents of early cinema. This is followed by a montage of stills from the same period of Blackfeet women at a government feeding station. These are shocking images. Over this we hear a seános lament (traditional Irish singing in Gaelic) which in a strange way resonates with the images of native American suffering. We return to another interview piece from Gary who links the historical theme to the contemporary parlous state of the Blackfeet in Montana. This voice is partly dubbed over a montage of contemporary shots of the impoverished Blackfeet town of Browning in northern Montana. The Gaelic lament continues and we cut to Ford Collection archive shots from the 1920s of native Americans at a Christian evangelical camp and over this we hear Mac Gabhann again and cut to contemporary shots of drunken residents of Browning gathered in an alleyway.

There was neither peace nor comfort for them anywhere. They'd come to a little valley pushed from their traditional lands by the settlers and start to work on the rough ground until they'd turn into a fine rich field stretching as far as the eye could see...

As soon as the American authorities heard about this they'd send a large army from the so called "civilised" part of America to drive these poor people further into the remotest reaches of the hills...

We were also interfering with them, I suppose, as well as everybody else, but at least some of us sensed that if they were bitter it was not without cause

Mac Gabhann's narrative then becomes more specific and experimental as he recounts the story of a fellow miner's wife kidnapped by Indians and rescued by a group of miners including himself. This story is "covered" 
not with the archive of a factual character but with a re-cutting of a segment from DW Griffith's 1914 movie The Battle of Elderbush Gulch.

As in the rest of the film a rich weave of archival images, both still and moving, factual and fictive, accompanies a spoken narration based on an original text. Present and past, indexical photographic trace and imaginative re-telling, are brought into creative alignment in a manner which hopefully both moves the viewers and causes him/her to question what they are seeing and what the narrator is telling them. Klondike seeks to offer a filmic treatment of memory and the past, which provides a critically inflected representation of the past in and through an engagement with contemporary issues. The collision of past and present and of different sorts of documentary images and sounds provides for an interrogation of an Irish popular memory fixated on displacement and emigration but perhaps less attentive to the role of the Irish in "the struggle for the frontier" with all that entailed.

The archival image as it features in the found footage film has a dual nature. It retains its indexical character reporting on an original site of capture and record. The importance of photography as record - which recent semiotically influenced theories of the medium have been reluctant to acknowledge - was recently brought home to me. After a screening of The Last Storyteller in the west of Ireland an elderly lady from the audience stood up to point out to me that a 1947 archival sequence which I had used in my film and which portrayed a family of cottiers working on their holding in the Irish speaking part of Galway, contained an image of her as a seven year old child! She was able to tell me in considerable detail about the production of the short documentary film which was my source. The film had been made by a visiting Welsh scholar on an "ethnographic" trip to understand the Gaelic culture of Connemara who had lodged with her family. This was the first time she had seen the film since she was a child.

So the archival image provides for a retrieval of a vanished past. However its appropriation by the found footage filmmaker and assembly alongside other found images takes place within a discursive world of cinematic signs and meanings. The Connemara footage which I had cut into Storyteller was used to portray the daily life of another marginalized Irish-speaking community - that of the Bluestack Mountains in Donegal two hundred miles north of Galway. Storyteller explores the role of the fairy story within that culture. The Connemara footage was intercut with archival footage of World War II German bombers unleashing their lethal load over open countryside in a montage which sought to link life during the war in these isolated rural communities to the historic events shaking Europe. The counterpoint of peasant folk life and war footage sought to provide a historical context to the cottiers' continued enthralment to fairy lore and the supernatural while acknowledging the historical reality that during the war German planes were regularly flying over this area after conducting bombing raids on Belfast and Derry in Northern Ireland.

While it is reassuring to believe that the archival images given life within films like Klondike, Storyteller or Rebel Frontier offer unmediated access to history, it might be more accurate to see their use in these films as essentially allegorical. For the filmic montage based on found footage is always a figuration of the past rather than a simple index of it. Clearly the archive image can only do this representational work when the indexical properties of the photographic image are put in brackets and the image qua sign attended to. Note I say with due deference to the phenomenological method "put in brackets" and not simply abandoned. For the archival image clearly alludes back to a "profilmic past" and to the relationship of the camera to what was once a lived present. And of course this referentiality is as true of fictional found images as it is of ones with factual auspices (which incidentally may be one of the reasons that in the making of Klondike we were able to draw with equal fluency on early silent film fictional material as actualities in our retelling of Mac Gabhann's story).

Our use of found footage seeks to acknowledge the essential ambiguity of the image within documentary film practice. Certainly in our use of archive we seek to remain sensitive to the duality of archival images that have been transformed by their removal from an original filmic context and inclusion in a new narrative structure within which they assume a new power of signification while clearly retaining that indexical lineage. As Russell argues (1999:238), in the compilation film,

The found image doubles the historical real as both truth and fiction at once document of history and unreliable evidence of history. 
As we have found again and again when selecting images with which to tell our historical stories, while the indexicality of the image chosen does not make it more real in any absolute sense, it does seem to grant to the image the power to effectively represent the past as engaging story and lesson for the future. Thus for example in another clip from the Connemara footage used in Storyteller, the young Welsh ethnographer visiting the Irish speaking communities of Galway stands in for the absent folk lore collector Seán Ó hEochaidh whose field work notes provide the narration for a film about traditional storytelling.

And in re-inscribing these images in new narrative contexts, hopefully we encourage the viewer to question the status of the representations they encounter. On the one hand, our found images seem to display an uncanny similitude to the audio- images conjured up by the spoken story, a similitude which owes much to the skill of editor Roger Buck. On the other hand, they retain their essential difference to these. For the images we assemble remain photographic documents of a specific time and place yet able to speak to our future.

For the historical images of cinema remain more than museological objects. When brought into collision and creative and critical alignment by the practice of montage employed within the found footage film, they take on a new life. I would like to think my films are developing a creative strategy for appropriating the past and preserving popular memory while at the same time making us aware of the sphere of historical representation as a site of struggle.

In the found footage film the indexical images of our cinematic past can be seized upon and their dialectical potential released in order to produce as Benjamin would have understood it, a "radical act of memory". The found footage film involves then an engagement with historical representation and with popular memory and facilitates an opening to different histories and marginalised voices and as the anthropologists would say, to the "time of the other".

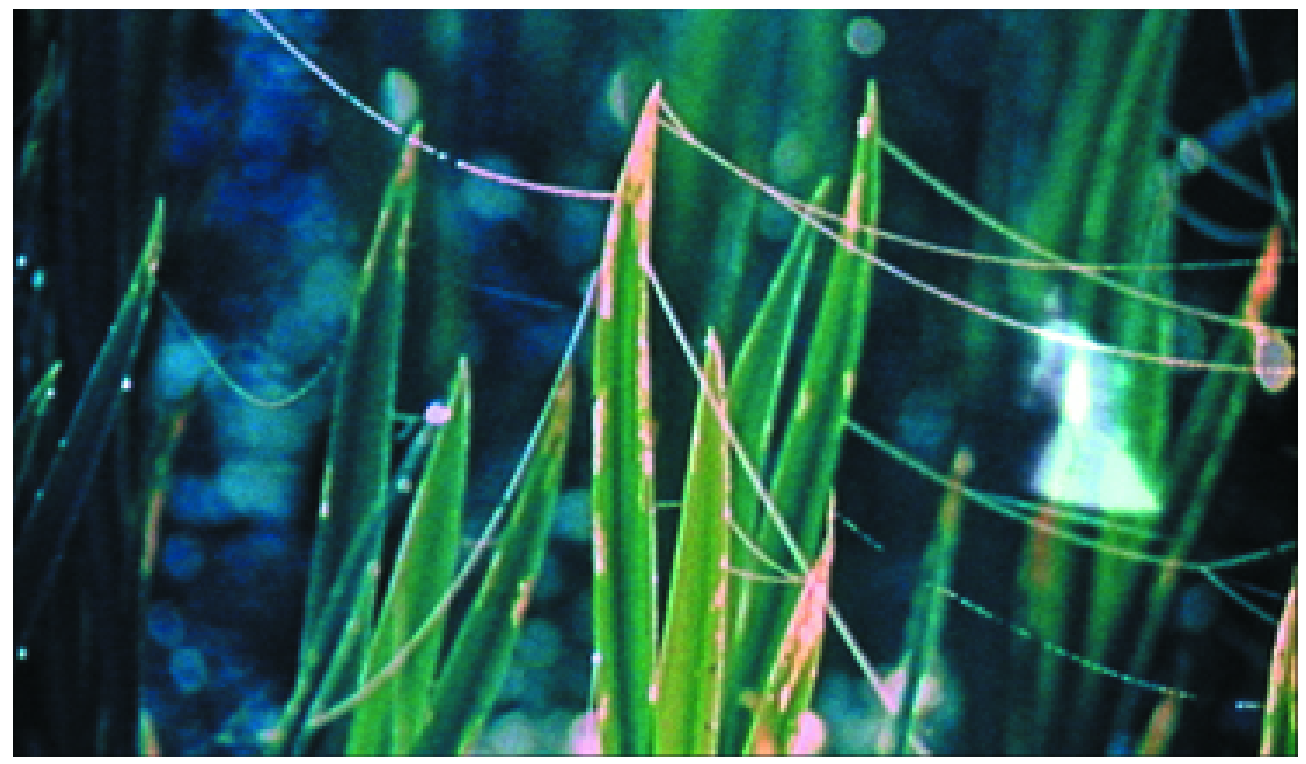

Figure 1: The Last Storyteller? (Dir. Desmond Bell, 2002)

\section{Notes}

1. The Hard Road to Klondike was selected for the 1999 Venice Film Festival and was invited to a range of other international festivals including Montreal, Cork, Minneapolis, Amiens. The Last Storyteller? was selected for the 2002 Venice Film Festival.

2. Although as Paech [1989: 59] reminds us, ontological theories of the cinematic sign of the sort espoused by Bazin and Kracauer were developed in relation to the quest for cinematographic realism in fiction words and 
not immediately applied to documentary practice with its ethnographic materiality and didactic interests.

3. Bruzzi [2000] amongst others has criticised the evolutionism present in Nicholl's typology suggesting that 'it imposes a false chronological development onto what is essentially a theoretical paradigm' and that his typology cannot explain for instance the experimental and reflexive films of a pioneer like Vertov.

\section{References}

\section{Bibliography}

Bazin, André. Qu'est-ce que le cinéma. Paris: Editions definitive, Cerf, 1981.

Bruzzi, S. New Documentary: A Critical Introduction. London and New York, Routledge, 2000.

Gabriel, Teshome. "Third Cinema as Guardian of Popular memory: Towards a Third Aesthetic," in Paul Willemen and Jim Pines (ed) Questions of Third Cinema, London: BFI.

Gunning, T. D. W. Griffith $\mathcal{E}$ The Origins Of American Narrative Film, Urbana and Chicago: University of Illinois Press, 1994.

Kracauer, Siegfried. Theory of Film, London: Oxford University Press, 1960.

Paech, J. "The Mummy Lives!," in W. De Greef \& W. Hesling (Eds) Image, Reality, Spectator: Essays on Documentary Film and Television, 1989.

Mac Gabhann, M. Rotha Mor an tSaoil. Dublin: Foilseachain Naisiunhta Teoranta, 1959.

Nichols, Bill. Blurred Boundaries: Questions of Meaning in Contemporary Culture. Bloomington and Indianapolis: Indiana University Press, 1994.

Ó hEochaidh, S et al. Siscéalta Ó Thir Chonaill: Fairy Legends of Donegal. Dublin: UCD, 1977.

Nichols, Bill. Introduction to Documentary. Bloomington and Indianapolis: Indiana University Press, 2001.

Russell, C. Experimental Ethnography: The Work of Film in the Age of Video. Durham and London: Duke University Press, 1999.

Wittgenstein, L. Tractatus Logico-Philosophicus, ed. by D. F. Pears, 1981.

\section{Filmography}

Badlands, Terence Malick 1973.

Decasia, Bill Morrison, Hypnotic Pictures, 67 min, 2002.

Film of Her, Bill Morrison, Hypnotic Pictures, 12 min, 1996.

Free Fall, Peter Forgács, Hungary, 75min, 1996.

One Man's War, Edgardo Cozarinsky, Channel Four TV, 52 min, 1988.

Out of Loyal Ulster, Desmond Bell, Channel Four TV, 52min, Glass Machine Productions/ Faction Films, 1994.

Redeeming History, Desmond Bell, Channel Four TV, 52min, Glass Machine Productions/ Faction Films, 1991.

The Butcher Boy, Neil Jordan, Ireland, 1997.

The Hard Road To Klondike (Rotha Mór an tSaoil), Desmond Bell, RTE/BBC:NI, 52min, Glass Machine Productions, 1999.

The Last Storyteller?, Desmond Bell, RTE, 52mins, Asylum Pictures/ Besom Productions, 2002.

Wittgenstein, Peter Forgács, Magyar TV, Hungary, 6x5min, 1994. 


\section{Author Information}

Desmond BELL is Head of Film Studies at Queens University Belfast and a documentary film maker. He writes on film and media in Ireland. His film The Last Storyteller? was selected for the New Territories section of the 2002 Venice Film Festival; his Rebel Frontier (2004) is a creative documentary dealing with the Irish and the Finns in the US labour movement. 